This item was submitted to Loughborough's Research Repository by the author.

Items in Figshare are protected by copyright, with all rights reserved, unless otherwise indicated.

\title{
The inevitability of corruption in Greek football
}

PLEASE CITE THE PUBLISHED VERSION

http://dx.doi.org/10.1080/14660970.2017.1302936

PUBLISHER

(c) Taylor \& Francis

VERSION

AM (Accepted Manuscript)

PUBLISHER STATEMENT

This work is made available according to the conditions of the Creative Commons Attribution-NonCommercialNoDerivatives 4.0 International (CC BY-NC-ND 4.0) licence. Full details of this licence are available at: https://creativecommons.org/licenses/by-nc-nd/4.0/

\section{LICENCE}

CC BY-NC-ND 4.0

\section{REPOSITORY RECORD}

Manoli, Elisavet, Georgios A. Antonopoulos, and Alan Bairner. 2017. "The Inevitability of Corruption in Greek Football". figshare. https://hdl.handle.net/2134/23974. 


\title{
The Inevitability of Corruption in Greek Football
}

\begin{abstract}
From the late 1990s corrupt practices in Greek football have been considered to pose a serious threat to the integrity of the sport, with a number of schemes and measures being introduced as a response. The aim of this article is to show why corruption in Greek football is inevitable by offering a detailed account of three football-related corrupt practices and highlighting their contextual parameters, as well as juxtaposing them against the set of measures that have been implemented. By placing corruption in football in the wider landscape of the country and of global football, and examining the political, structural and economic factors that contribute to the overall managerial and financial implications of corruption, we present the reader with the new norm which, in reality, makes corruption the 'only game in town'.
\end{abstract}

Keywords: Match-fixing, ticket tricks, fake tax certificates, corruption in sport, tackling corruption in sport

\section{Introduction}

From the late 1990s corrupt practices in Greek football have been considered as a serious problem for and threat to the integrity of the sport in the country. But to what extent, if any, can these problems be regarded as unique to Greece? After all, corruption has been revealed as rife throughout world football, not least at the highest levels of the game. ${ }^{1}$ On the other hand, if the problems to be discussed in this paper have a uniquely Greek character, perhaps 
this should come as no great surprise either given the ongoing debate about levels of corruption in Greek society more generally. For example, Antonakas et al suggest that "in Greece corruption appears to be a powerful element in the functioning of certain public services", noting in passing in the late $5^{\text {th }}$ century, Pericles and Phidias were brought to trial for abuse associated the construction of the Acropolis monuments. ${ }^{2}$ Numerous reports by Greek government institutions as well as by international organizations and NGOs have demonstrated that corruption levels in Greece are extraordinarily high for the country's level of development. Transparency International's overall Corruption Perception Index score for Greece have consistently been closer to those of Central and Eastern European countries in transition than to those of Western Europe. ${ }^{3}$ In Greek football, therefore, we have arguably the making of a perfect storm.

However it is too simplistic to trace corruption to national traditions and culture. As Lambropoulou rightly argues, "Corruption is neither an issue of morals nor of embedded attitudes; it is the result of serious social and organisational problems" which are unlikely to be solved without major social change. ${ }^{4}$ When there is unwillingness to embark on change of the necessary magnitude and those innovations that are introduced fail to address the fundamental problems, corruption will persist. It is with this in mind that we argue, while accepting that corruption is problem for global football and a significant factor in Greek society, it manifests itself as an inevitable aspect of Greek football.

To a great extent corrupt practices in Greek football were initially associated with the existence of the 'paranga' (literally, 'The Shanty') which refers to a mechanism for fixing games by selecting specific referees for specific games in order for particular clubs to benefit. The ultimate goal of the 'paranga' was for a particular club to win the Greek league title as 
this is associated with significant income from Champions League games and television rights. ${ }^{5}$

Following the exposure of fixed matches in Greece in 2011, also known as Koriopolis (a pun name on the Italian scandal Calciopolis and a play on the Greek word 'korios' or phone-tap), detailed information about numerous matches played in the 2008/09, 2009/10 and 2010/11 seasons that attracted UEFA's attention were brought into the public eye. ${ }^{6}$ Greek football has also attracted considerable attention from UEFA in light of other scandals including 'shady' football club owners' imprisonment. This led the national and international media to portray Greek football as a 'mafia-type' organisation, especially after the former president of the Hellenic Football Federation was accused of being involved in a 'criminal organisation' that was allegedly directed by the current President-Owner of Olympiakos. ${ }^{78}$

In response to these events, both the national governing bodies of the sport and the Ministry of Culture and Sport have introduced a number of schemes and measures since 2011 in addition to the existing relevant national legislation (such as the Law 2725/1999 on 'Amateur and Professional Sports') and international legal frameworks (such as the UN Convention Against Corruption and the UN Convention Against Transnational Organised Crime). ${ }^{9}$ These include educational workshops delivered to young players that will be discussed in more detail in a following section.

The measures taken to tackle corruption have been introduced and implemented in the top tiers of professional football and were met originally with enthusiasm since they were seen as an effective way to protect and enhance the 'product' of Greek football. ${ }^{10}$ However, it can be argued that there has been no success in stamping out corrupt practices in Greek football as is 
exemplified primarily - among other examples - by ongoing discussion about how integral match-fixing in the country has been ${ }^{11}$, a discussion that now has spilled over outside the country, as well as an enduring distrust among football fans towards the 'product' itself and the authorities that supposedly regulate and promote it. ${ }^{12}$ Mplounas' study shows that the Greek public has lost interest in domestic football because the image of Greek football is regarded as 'bad' and its quality 'low'. ${ }^{13}$ The public considers that the factors that contribute to the negative image and low quality of Greek football include the systematic bias of the organisers of football leagues in favour of specific clubs $(91.5 \%)$ and the tolerance of the government towards criminal and corrupt practices in football (86.5\%). In addition, the public consider that a significant number of football matches' results in Greece are a product of match-fixing and that referees are considered to be an integral part of the match-fixing process. $^{14}$

This negative perception appears to be the case among players too which is highlighted not only by reactions to match-day injustices suffered by specific football clubs but also by a recent report that reveals that $12.8 \%$ of Greek football players interviewed admitted that they had been approached to 'fix' a match within the past year, and $64 \%$ of them said they were confident that matches in their league were fixed. ${ }^{15}$

The aim of this article is to show why corruption in Greek football is inevitable by offering a detailed account of a number of football-related corrupt practices and highlighting their contextual parameters as well as juxtaposing them against the set of measures implemented in response to football corruption in the country. ${ }^{16}$ Through the analysis of the data collected, three major areas of football-related corruption were identified: match-fixing; ticket 'tricks'; and tax evasion through fake tax and insurance certificates. Although this is hardly an 
exhaustive list of corrupt practices in Greece, these areas were selected because they have either received considerable media attention, or because they have been identified as 'normal' practices in the working of the Greek football clubs that have been the context of our empirical research. This is why doping, for instance, is beyond the scope of our study. ${ }^{17}$ For the purposes of this article, we use Gorse and Chadwick's definition of sports corruption: "any illegal, immoral or unethical activity that attempts to deliberately distort the result of a sporting contest for the personal material gain of one or more parties involved in that activity". 18

Our goal is neither to offer a systematic analysis of the causes of football corruption in Greece nor to provide an account of every type of football-related corruption in the country. Moreover, we do not have the objective of evaluating the measures implemented against football corruption in Greece. On the contrary, our sole aim is to examine the corrupt practices in detail, along with the measures taken against them, while highlighting the factors which suggest that corruption is an integral and, we argue, an inevitable aspect of Greek football, based on the approach followed by causation and effect studies. ${ }^{19}$

The article is structured as follows: initially, an account of the data and methods utilised for this study is offered followed by a presentation of the measures against corruption that have been introduced in Greek football over the past years. Then we offer an examination of three major types of corrupt practices, in an attempt to highlight the key actors and underlying structures that support them. We conclude with a discussion of our findings.

\section{Data and Methods}


The primary source of information for this article is ethnographic research conducted by the first author while employed on a full-time basis by two football clubs in Greece. One of the clubs is one of the leading and most popular clubs in country and a member of the Super League (first division), whereas the other is a historic club in the second division (also known as 'Football League' in Greece). The ethnographic approach offered the researcher a unique opportunity to study individuals who seldom present themselves for examination. This part of the research required immersion in the field for a significant period of time (from August 2008 to February 2011 and from April 2011 to April 2013), and participation in activities that were not related to the collection of data per se. Within the context of the ethnographic research, additional information on the issues at stake was obtained through interviews with informed actors from the realm of Greek football.

Secondly, with regard to match-fixing in particular, we used telephone conversations that were available as the result of wiretapping by the National Intelligence Agency $(E Y P)$ in relation to the latest football match-fixing scandal (2011). These wiretapped conversations offer abundant information about the broad range of actors and groups involved, and identify patterns of social organisation across a number of cases, many of which were related to one another. Finally, we collected, examined and analysed published media sources which allowed us to obtain information not only about the process that lies behind corrupt practices within football clubs, but also about the key actors involved. Articles from the five newspapers with the highest circulation in the country were selected, namely Eleftherotypia, Kathimerini, Ta Nea, To Proto Thema and To Vima, whose focus is political, not sport specific. ${ }^{20}$ The results were triangulated with data collected through the first two methods. 
As with any such study, there were some limitations which should be acknowledged. The first one has to do with the ethnographic part of the data gathering. There can be no guarantee that the information given is a wholly neutral representation of the activities observed and the links between various actors. Although the researcher tried as far as possible to be an objective observer, one needs to remember that accounts offered in an ethnographic study are always consciously or unconsciously interpreted by the researcher. In addition, the data are largely limited to what the participants have offered and what the researcher has observed, and they cannot be generalised to the whole football scene. In relation to the interviews with the informed actors, there are further issues of generalisability, and one can never be absolutely certain about validity, even though 'cross-checking' and 'member checking' significantly contributed towards eliminating untruthful accounts. Furthermore, there is also the issue of the representativeness of the sample. As in many instances, the researcher used the snowballing sampling method to identify participants, thereby limiting the sample to the researcher's own personal network and, as a consequence, the scope of the findings.

The second set of limitations is related to the wiretapped conversations provided by the Greek National Intelligence Agency. These are the result of law enforcement activity, which in turn is affected by resource restrictions, the competency of agents, organisational priorities, and wider political priorities. As with any product of the state derived from largely unaccountable agencies, wiretapped conversations need to be carefully handled and the extent to which their revelations can be applied beyond the affected clubs remains uncertain.

The final set of limitations is related to media sources. Not only do they most often refer to those cases which the authorities came across, thus potentially ignoring 'successful' strategies, but they also tend to present the issues relating to the actors or the activity/market 
itself in a sensational and morally charged manner. Nevertheless, we believe that the methodological triangulation employed throughout the study - involving both official and 'unofficial' sources - has created a net that has captured the most important aspects of the topic under investigation and that the findings possess a high degree of validity.

\section{Tackling corruption in Greek Football}

The measures against corruption that have been introduced in Greek football in recent years (following the latest match-fixing scandal exposure in 2011) include educational programmes and tighter regulations in relation to both financial control and match-fixing detention, which will be described in more detail below. Presenting them will allow for a thorough understanding of the response to corruption, while simultaneously highlighting the actors and areas upon which these have been focused.

Two educational programmes were designed and run by the Greek Super League and the Hellenic Football Federation. The first, 'Staying on side: How to stop Match-Fixing' was an educational workshop introduced by the Greek Super League and delivered to young players (playing in Under 17 and Under 20 national championships) who are urged to care for '[their] team, [their] career, [their] responsibility' (according to the programme's motto). ${ }^{21}$ This programme ran for the duration of one season and was aimed at raising awareness of the effects match-fixing can have on the future of the sport and each individual player's career. More than 800 players and coaches attended the workshop and were informed about the repercussions of match-fixing, based on the principle that ethics and integrity can be taught and, as a result, key actors can be trained to support fair play and reject corruption, leading to 
a better future for football. ${ }^{22}$ The programme was sponsored by 'Transparency International', which aims at addressing corruption in all aspects of modern life. ${ }^{23}$

The second set of programmes consist of educational courses run throughout the last few seasons, promoting fair play and ethical conduct in football to high school students. ${ }^{24}$ Through these courses, the students were informed of the idea of fair play in football and were given the opportunity to appreciate the benefits of following such practices with regard to enjoying the sport and protecting its future. The programme was supported by the country's major football clubs which urged their players to deliver some of the courses themselves. These courses were delivered in schools around the Greek capital and were welcomed by local authorities and the Ministry of Education.

Both 'Staying on side' and the fair play programmes were run in conjunction with the European Professional Leagues Association (EPFL) with the initial aim of educating potentially key actors in order to prevent match-fixing and non-fair play behaviour in general. By educating these individuals about the effects their decisions can have, and allowing them to visualise the repercussions of their actions, prevention of corruption was to be achieved. ${ }^{25}$ The basis on which the programmes were designed follows the INTERPOL-FIFA AntiCorruption Training Initiative, which began in May 2011 with 'the overall objective of tackling sport corruption in football, with a principal focus on illegal and irregular betting and match fixing, through providing various training programmes to improve key individuals ${ }^{26}$ According to the Anti-Corruption Initiative, protecting the integrity of football can be supported on three pillars; training, education, and prevention. All three entail raising awareness of the phenomenon of match-fixing and the ways in which each individual actor can resist and report match-fixing, as well as how information about match-fixing can be 
shared between international organisations, in order for transparency in updates on the phenomenon to be ensured. ${ }^{27}$

Additional measures for addressing corruption at a European level have focused on the appropriate governance of the sport, which as Jones suggests, resembles the way in which problems would be dealt with in the corporate world. ${ }^{28}$ Measures have included the introduction of tighter financial regulations on clubs, which was supported in UEFA's financial fair play guidelines, and the establishment of firmer control over key events, such as match-days, through each league's 'independent official auditors'. ${ }^{29}$ The financial regulations imposed called for additional transparency in the accounts of each club, while ensuring that any money owed either to companies and individuals or to the country would have to be paid in order for clubs to be permitted to participate in the season's championship. Introducing a centrally controlled electronic tax system is intended to allow for each club's ticket issue (one of the key income sources) to be managed and regulated more closely, while eliminating room for individual errors or favouritism. ${ }^{30}$ Appointing independent official auditors' to each club on match-days would then ensure that detailed reports on these key events would be provided to the pertinent governing bodies, tax authorities and police.

Finally, tighter control of betting was regarded as a priority, having been identified as a major factor in football corruption. Additional and firmer control was assisted by the introduction of the UEFA Betting Fraud Detection System (BFDS) which allows for all legal betting activities world-wide to be monitored, in order for any irregularities to be noticed. ${ }^{31}$ Such irregularities include unexpectedly high activity on significantly favourable odds for rather unanticipated results before and especially during matches. The system makes it possible for these activities to be identified and for the betting system supporting them to be blocked. The 
BFDS has also been used to thoroughly review matches that have already been concluded, especially when suspicion has been raised due to unexpected events taking place within their duration. The system further enables the analysis team to examine these matches carefully and decide whether they can be considered 'questionable' or 'exceptionally questionable'. Once a match has been assigned to either of these two categories, the relevant national football association is informed so that an investigation can begin. Interestingly, 41 Greek Super League and Football League matches played between 2008 and 2011 were considered to be 'exceptionally questionable', according to the system, obliging the Hellenic Football Federation to investigate them further. ${ }^{32}$ It is also worth noting that a significant number of Greek matches are being reported each season as 'questionable' or 'exceptionally questionable'. 33

\section{Corrupt football practices in Greece}

As mentioned earlier, through the analysis of the data collected, three major examples of corrupt football practices can be identified: match-fixing; ticket 'tricks'; and tax evasion through fake tax and insurance certificates. These examples will be discussed here in some detail, with a focus on the individuals and structures that have not been addressed by the corruption prevention schemes presented above.

\section{Match-fixing}

The match-fixing web revealed through the official case files of the Koriopolis scandal, appears to comprise a complex figuration of a number of actors, participating willingly or unwillingly in order for the events and final results of particular matches to be set according to pre-arranged agreements. The actors involved in match-fixing range from those individuals 
who initiate the process to unwilling members who participate under the threat of physical harm. As the following analysis will show, only a few of these individuals have been involved in the prevention programmes, with the initiators of the whole process, in particular remaining, not yet addressed.

As was presented earlier in the study, the educational prevention programmes have targeted young players and potential managers, while neglecting the professional footballers currently playing in the top tier of Greek football. Yet, due to their role as key constituents in the process that can secure a desired result for a match, players have been participating in matchfixing willingly or unwillingly. It has often been suggested that their involvement was a result of intimidation or fear imposed on them by the owners or presidents of the clubs. However, while threats have been recorded as a successful means of ensuring collaboration in matchfixing, additional evidence suggests that players' involvement in the process can in reality be an informed and even calculated decision. In fact, this was argued by a player on one of the many occasions when one of the authors was present

I had to do it [ensure a particular result was achieved]. All five of us [pointing to an additional four players] were in. We got some good money out of it and it was so easy. They're not paying us enough, so we have to find another way to make money'.

Footballers may well be aware of the repercussions their actions can have, but they choose to neglect these in order for 'easy and quick' profit to be gained. However, closer scrutiny of the transcripts provided by EYP suggests that the Presidents (owners or chairmen) of the clubs are the individuals who initiate the process of match-fixing and ultimately ensure that the agreed result of each match will be achieved. 
According to the transcripts of recorded conversations, the Club Presidents, after being informed of a favourable betting rate for a match involving the club which they own or lead, will attempt to reach an agreement on the required result that would secure them that rate. This agreement is either reached with the President of the club they are playing against, the referee, or the players of either or both clubs. This mechanism whereby an agreement is reached entails either the promise of reward ('I'll give you the number of my booker and you can bet a few grand on it and get a little something for yourself'), or the threat of harm to someone's career or physical health ('if you don't do it, my boys will break your legs and you won't be able to kick a ball ever in your life'). The Presidents are also in charge of ensuring that the desired result is achieved and are, therefore, in regular contact before and throughout each match with those individuals who are involved in the agreement.

Another category of key actors that have not been addressed by the new measures is one that was involved in one of the biggest scandals in Greek football in the early 1990s, namely referees. The referees' role entails executing, rather than initiating, the match-fixing agreement. Their power depends on exerting significant influence on the final result of a match through the decisions they make. Based on this power and on the fact that their decisions cannot in practice be disputed, a pre-arranged result can be achieved through referees' collaboration. The first highly documented match-fixing scandal in Greece in the '90ies was in fact structured around a mechanism of fixing matches by selecting specific referees for particular matches in order for the outcomes of those matches to be decided. ${ }^{34} \mathrm{~A}$ number of referees have in fact faced legal action against their involvement in both recent match-fixing scandals. ${ }^{35}$ As the data show, referees have agreed to influence the course of matches in order for desired results to be attained, by making wrong decisions or turning a 
blind eye at key moments during matches. Once again, the evidence suggests that both rewards and threats have been used to convince referees to participate in match-fixing.

Finally, bookmakers or illegal agents have also been identified as key actors in match-fixing, since they provide the incentives that predominantly create the need for this phenomenon. ${ }^{36}$ Whether legally or illegally, the betting rates they set and promote act as inducements for any of the above mentioned actors who decide to fix a match. Even though tighter control measures have been implemented by both international and national governing bodies (FIFA, UEFA, the Greek Super League) and local betting providers (OPAP), as was discussed earlier in this paper, betting still remains widely uncontrollable.

As the above analysis of match-fixing has demonstrated, the individuals involved in the process include groups that are not currently addressed by the strategies and structures that have been introduced. Indeed, the structure of this complex web is not even sufficiently examined for the true underlying issues to be identified. Additionally, even within groups that the current programmes have captured, the element of intent behind their choice to participate in match-fixing is not addressed.

\section{Ticket tricks}

Football clubs rely heavily on income from match-day ticket sales, particularly in lower

divisions where the agreements about sponsorship and TV rights are not very lucrative. ${ }^{37}$ However, compared with the other sources of income, ticket sales have also been considered the least controlled income stream since the actual transaction is completed when the exchange of money for a paper ticket takes place, without any additional paper trail. In order 
for this income source to be more closely monitored, additional measures have been introduced that have included detailed reporting of the tickets sold and the appointment of 'official league auditors' for each match. ${ }^{38}$

The process of selling and reporting the tickets sold (through which the taxable income is also calculated) is further problematised by the existence of an additional match-day ticket category to which most people do not have access. This category, known as season (card exchange) tickets, was originally created in order for an account to be kept of the number of season ticket holders that attend each match, while allowing for the income generated through the season tickets to be distributed throughout each season. According to this process, the tax authorities would then rely on each club to report the exact number of season card exchange tickets validated at each match, representing the number of season ticket holders who had attended, which is then used to calculate the income tax liability of the club for each match. The process would require each season ticket holder to visit the ticketing office before entering the stadium, in order for him or her to get an additional paper exchange ticket. The validation of these tickets would then take place when entering each stadium, and would be overseen by both security staff and the league's 'official auditors'. 39

The way in which this process takes place in practice, however, deviates from the original plan. The league's 'official auditors' rarely oversee the validation process in detail, and instead prefer a more indirect method of calculation. At the end of each match, the auditors provide the ticket officers of the home club with a rough estimate of the number of season ticket holders who have entered the stadium, in order for the corresponding exchange tickets to be 'validated'. Since validating the exchange tickets using an actual validation machine 
would be futile at this point, the 'validation' that takes place involves manually shredding the tickets that should have been given to the season card holders before entering the stadium.

Interestingly, the estimated number suggested by the 'auditors' is rarely undisputed. On the contrary, this number becomes a negotiation topic between the auditor and the head of the ticketing department of the club who aims to reach agreement on the lowest number possible. The auditor is often asked to be understanding and lower the number substantially and this is regularly achieved. The final number agreed is then documented in the official reports of the match which are then signed by the auditor and submitted to the tax service, the local police and the league's governing body. These reports will be also used by the club accountants in order for the tax liability to be calculated. It is worth noting that this negotiation is anticipated by both parties and even encouraged by higher league officials. On one of the many occasions when one of us was present, an auditor admitted that he was planning to be understanding towards a particular club, since one of the vice-presidents of the league in which the club was playing had personally asked him to.

However, requesting the auditors' consent to disobey the laws is not limited to the above mentioned negotiation. A more complex and demanding negotiation process can also take place on the occasion of a club being unable to issue an adequate number of match-day tickets caused either by financial problems (lack of tax or insurance certificates, for example, as discussed below) or a simple miscalculation of likely demand. The auditors are then asked to agree to 'turn a blind eye' in order for unofficial tickets to be used, thereby allowing for an exchange of money to take place without any paper trail. The process that they are in fact agreeing to overlook involves the selling of unofficial tickets that have not been issued by the relevant governing body or stamped by the local police and tax service. The result is 
untraceable and therefore un-taxable income for the club. In other words, the auditors are asked to sign the official reports stating that no additional tickets were sold while unofficially allowing non-ticket holders to enter the stadium.

Surprisingly enough, this complex negotiation has proved successful and has even been encouraged by the league's administration. It is worth noting that on one occasion when one of the authors was present, a vice-president of the league in which a particular club was playing joined the auditor and the director of the ticketing department before the negotiation began and told the auditor to 'look after those guys as best as [he] can'.

\section{Fake tax and insurance certificates}

On the basis of the additional control measures introduced by the governing bodies of the sport, in collaboration with the Ministry of Culture and Sport and the Ministry of Finance, more thorough procedures were gradually introduced for football clubs. As a result, and in order to complete key tasks, such as signing a new player, getting permission to participate in the championship or even issuing tickets for the next home match, an additional step has had to be taken. A tax certificate or an insurance certificate has to be obtained from the local tax authority or employees' trust fund. ${ }^{40}$ A tax certificate can be issued when the club has settled any tax liabilities owed to the government, by either paying the debt off or by agreeing to a repayment scheme. Similarly, an insurance certificate is issued when the club has settled any outstanding debt regarding the employees' national insurance contributions, by paying it off or by reaching a settlement with the trust fund. By making one or both of these documents compulsory the governing bodies have ensured that the clubs should be kept 'on a short leash' regarding their payments to the government and the employees' insurance contribution. 
However, Greek football clubs have succeeded in discovering creative ways to avoid this additional hurdle and continue their 'questionable' practices with significant short-term success. Firstly, securing a number of consecutive settlement agreements can 'buy' a club some valuable time, ranging from one to two months i.e. from the moment an agreement is reached to the moment it collapses at which point the next agreed payment becomes overdue. This short time window can allow for the certificates required to be issued and tasks in hand to be completed, without any additional payments being made to either the tax or the national insurance debt. Secondly, using personal connections in the local tax service or the local employees' trust fund office in order for exceptions to be made regarding the club, has been a popular practice, especially on the part of football clubs located in provincial areas of Greece. Favouritism, or simply asking employees to turn a blind eye when a club has been unable to obtain a new tax or insurance certificate, has proved to be particularly successful in Greek football, with a number of smaller clubs succeeding in completing various crucial tasks, such as issuing tickets for the majority of the matches of the season, without a valid certificate having been issued. This practice is gradually being abandoned by the clubs, since the newly introduced online countrywide filing system does not allow for individual employees to alter or omit any of the required steps, making it increasingly difficult if not impossible for favouritism to succeed. ${ }^{41}$

Thirdly, a rather risky and even more creative way of avoiding this additional hurdle was invented; this is the production of fake tax and insurance certificates. This practice attracted considerable attention, when a number of first division clubs, currently facing charges and possible relegation for their actions, were caught using fake certificates in order for new players to be signed and tickets for home matches to be issued. ${ }^{42}$ Regardless of the attention 
this practice has received, however, creating and using a fake certificate is still one of the most successful and common ways to overcome the additional controls in Greek football. According to this practice, a fake tax or insurance certificate is created by the employees of a club, who ensure that the final product looks identical to an authentic tax or insurance certificate. The only thing that differs from the prototype used is the protocol number, which is updated accordingly, in order for the employees receiving the document to be convinced. This fake document is then filed along with the other necessary documentation, depending on the task in hand. On the odd occasion when the fake certificate has to be delivered in person, for example in order for match tickets to be approved by the local tax service, the person in charge of presenting the document is offered additional advice on how to behave ('act natural', 'say that you don't know anything about it') and what to do if the fake document is identified ('call the President in case something goes wrong').

Finally, a documented way of avoiding the additional controls, which is often used when all the above described practices fail, is the use of personal political connections by the Presidents of the clubs. On such occasions, it is not the employees of the club asking local tax employees to turn a blind eye to a missing paper; it is the Presidents of the club asking similar favours from political figures who are then requested to use their power over the local or national authorities, so that the favours can be granted.

Given the secrecy surrounding this method, little information exists as to the identities of the individuals involved, or the actual discussions that take place between them. What can be presented, however, is an overview of how this method works. Firstly, once an unexpected problem occurs, the President of the club is notified and is provided with details about the issue. The President then approaches a well-known politician who is often a close personal 
contact, in order to request a favour for 'overcoming this obstacle'. Since this approach takes place privately and often involves a single phone call from one party to the other, little information exists on the identity of the politicians engaged in the process. What has been observed, however, is the third step in this method, namely the result of the political figure's influence. Depending on the nature of the problem, the politician makes the relevant authority (for example, the local tax service) aware of his or her personal interest and ensures that the particular authority stops the process. This step often entails a personal phone call made by the politician to the person blocking this progress (e.g. the director of the local tax service) who is then asked to 'turn a blind eye' in his or her favour. Even though information on the actual content of this phone call cannot be obtained, this method has proven to be particularly successful in Greek football. As a director of a local tax service confided to a club's employee during our research:

'I shouldn't really be doing this for you [signing the document that allowed the club to issue match tickets without a tax certificate)], but I am. I personally don't mind what happens with the club. But if he [referring to the politician and pointing at the phone] comes through, then I am happy. I want to keep him happy, because I don't want to be stuck here for long. He is a good connection to have and I want him to be happy with me'.

\section{Discussion}

In light of the fact that corruption in Greek football has significant negative repercussions for the sport and its management, the measures that have been introduced to deal with corrupt practices are, of course, positive developments. ${ }^{43}$ However, they tend to ignore important aspects, not least the actors and processes that are integral to the commission of corrupt 
practices. The educational programmes focus on players and prospective players while overlooking those actors who are instrumental in the commission of corrupt practices such as club presidents, referees and betting agents. Specifically, club Presidents have attracted considerable attention because they have included people with dubious legal or even criminal pasts and equally 'questionable' motives. ${ }^{45}$ It is worth noting that although a Fit and Proper test has been a law in Greece since 1999 (Law 2725/1999), in reality, it has never been actively applied. $^{46}$

Similarly, despite the numerous promises that the appointment and training of referees through the Hellenic Football Federation would become a transparent and closely controlled process, this has not been the case. Moreover, with regards to betting, one of the key drawbacks of the BFDS is that although the system can examine and control the legal betting activities worldwide, it cannot trace and, therefore, assist to restrain any of the numerous illegal betting practices. ${ }^{47}$ Unfortunately, as was underlined by UEFA, these practices account for $70 \%$ of overall betting activities globally. ${ }^{48}$ The existence of illegal betting agents often located in Asian countries and, therefore, operating under different regulations has allowed betting to remain a key incentive for match-fixing.

Even though tighter financial regulations were introduced gradually throughout the country and are now implemented in professional Greek football, a number of creative solutions have been invented in order to avoid situational constraints. The way in which these measures have been put into operation in Greek football has not stopped corruption. On the contrary, it has created the need for more elaborate or resourceful ways to maintain or even raise the level of corruption while exposing cultural and economic conditions that are conducive to corruption. $^{49}$ 
An important indigenous cultural condition favouring football-related corruption in Greece is politics (as is argued about numerous other countries, such as Lebanon). ${ }^{50}$ As Dimitropouloshas noted, Greek politicians have been unjustifiably favourable towards football clubs, either in direct or indirect ways, in fear of the significant political cost entailed in possibly denying them extravagant favours. ${ }^{51}$ As a result, the role political figures have played in this practice has not been addressed, allowing for this method to remain successful in overcoming any problems created by any of the new strategies aimed at preventing corruption. ${ }^{52}$ Perhaps unlike in other contexts, what happens in Greece is that the clubs participating in corruption are in essence protected from any significant punishment by local politicians. The level of interconnectedness between football and politics in Greece is exemplified by the fact that the current mayor of Piraeus (the home town of Olympiakos FC), Yiannis Moralis, who was elected in 2014, was formerly the vice-chairman of the football club, while the current mayor of Volos, Ahileas Beos (the home town of Olympiakos Volou FC), also elected in 2014, was previously the president of Olympiakos Volou. ${ }^{53}$

The measures that have been implemented also ignore or overlook the financial footballrelated context in the country, which is, of course, an extension of the general financial and entrepreneurial landscape in Greece. Firstly, since the beginning of the 1980s when the sport became 'professionalised' and football clubs in the first, second and third divisions were transformed into companies, football has been used as a platform for extremely powerful individuals to use clubs and the popular support for them not only as an income source per se (season tickets, advertisements, merchandise, etc.) which is particularly the case for big clubs, but also as a vehicle for tax evasion and money laundering, as a protection shield against the 
state, and as leverage for securing state bids. ${ }^{54}$ From the moment football clubs become companies that are to be protected as 'investments', sport itself becomes a secondary concern.

Moreover, the 'paranga' mechanism, mentioned at the beginning of this paper, has primarily facilitated corrupt practices in two ways: firstly, it has consolidated the extremely low 'outcome uncertainty' within the Greek football causing significant competitive imbalance among the clubs. ${ }^{55}$ This imbalance not only led to the creation of 'big' and 'small' teams, as Szymanski and Kesenne suggest, but also to the formation of 'rich' and 'poor' clubs. ${ }^{56}$ As Schmidt and Berri note, since the performance on the field in professional competitive sports has a direct impact on their financial income, the gap between these two groups is affected by the competitive balance or imbalance of the league. ${ }^{57}$ The low outcome uncertainty in Greek football has arguably led to high levels of competitive imbalance within the professional leagues of the sport, leading to the creation of 'rich' and 'poor' clubs, with the gap between these two categories being widened year after year as the clubs' financial records show. ${ }^{58}$

Another way of underlining this competitive imbalance within the league is to examine the level of probability of determining the winner of the league. ${ }^{59}$ Taking into consideration that the Greek Championship has been won by the same club 17 times within the last 19 years, outcome uncertainty has reached an extremely low level, with the Super League often being characterised as a 'monopoly', with all the financial implications that this entails. ${ }^{60}$ This has also meant that no other major clubs in the country have been able to profit from such an achievement creating a condition in which even major football clubs face deteriorating finances ${ }^{61}$, which could have been avoided with participation in Champions League, and being obliged to search for additional funding sources. 
In addition, the 'paranga' was instrumental in corruption becoming widespread in Greek football in the context of self-governance and autonomy of the Greek football where state monitoring is virtually non-existent. It created an environment of distrust in which most clubs had to 'pick sides' if they wanted to guarantee preferential treatment, better positioning in play-offs, avoidance of relegation, increased chances of promotion or playing in European competitions etc. This pervasive corruption in the world of Greek football has been demonstrated to act fundamentally to provide a comparative advantage to those structures which do not operate according to officially established rules. Inevitably, some corrupt activities such as match-fixing, in such an endemically corrupt environment, have become viable, rather short-term, solutions for many football clubs. It is also a way of making sure that money is being made despite the enormous financial pressure that most Greek football clubs face in the current entrepreneurial and financial landscape of the country. Reasons for the financial hardship of football clubs include the continuing reduction in clubs' income, especially after 2009 , reduced attendance at Greek stadia with an average of 4,328 spectators per Super League football match (and a reduction in attendance by $12 \%$ between 2008/2009 and 2012/2013), and the generally low commercial value (brand finance) of the Greek football. $^{62}$

Although these data might not be completely accurate, for the reasons given earlier in this paper, the order of magnitude is likely to be about right and gives an idea of the scale of the 'real' problem, which naturally has severe financial repercussions for individual players. In fact, the way in which players are treated in modern Greek football in terms of finances has led to numerous official complaints being made to the international governing bodies of the sport. These have in turn resulted in the International Federation of Professional Footballers 
(FIFPro) issuing an official announcement, advising players to avoid signing contracts with Greek clubs. ${ }^{63}$

"Unfortunately, many [Greek clubs] ${ }^{64}$ don't keep these promises. Generally, after a few months, the club turns out to be short of financial resources, so the player has to wait months to be paid. Very often, he never collects. Some players have to abandon their homes because the club cannot or will not continue to pay their rent. And bonuses are never mentioned again. A player who has to wait for his money has a greater chance of being approached to manipulate a match". ${ }^{65}$

Within the formation of this financial imbalance among clubs that was mentioned above, corrupt practices within football clubs are often the product of the pre-emptive fear of a club 'not making it' and losing its position in the football industry. ${ }^{66}$

\section{Conclusion}

The measures implemented to address corruption ignore the fact that corruption in the Greek football business world is no longer an aberration, a temporary anomic diversion for an industry normally guided by good values or a set of immoral actions taken by individuals who 'hide' behind the rules in order to disconnect from any moral responsibility. ${ }^{67}$ Morals have been relocated from the core to the periphery as guides to individuals and entities such as clubs that compete hard in the football business environment. ${ }^{68}$ With such a powerful amoral injunction at the core of the Greek the football industry, and with failure punished by 
the threat of extinction from the football scene, it is unsurprising that many will resort to largely undetected unethical or criminal means. ${ }^{69}$ Corrupt practices in the Greek football are not the intrusion of 'anomie' (normlessness) into the core of an industry by displacing traditional values and norms; they are the new norm. ${ }^{70}$

The measures implemented give the false impression of a capacity to accommodate ethical sociability but Greek football clubs must continue to make profits or 'die', and in difficult circumstances, such as those mentioned earlier, ethical restraints can easily be overridden. As financial pressures intensify in Greece in general and in the Greek football industry in particular, ethical restraints for a range of actors associated with football clubs are consistently undermined by corrosive forces that are operate on the football industry from the economy's pathogenic core. ${ }^{71}$ The aggressive neoliberal political economy that has spread to Greek football now presents us with corrupt practices as the 'only game in town'. 


\section{Notes}

1. See Jennings, The Dirty Game.

2. Antonakas et al, Human Resource Management in Corruption, 457.

3. See Transparency International, Greece.

4. Lambropoulou, Corruption in Public Administration, 78.

5. Kapranos, O 'Theios', 34.

6. Eleftherotypia, Krataei xronia afti i...mpoxa, 46.

7. Reuters, Olympiakos Champions League spot safe for now,

8. See The Telegraph, Match-fixing case in Greece, 17; The Telegraph, Good fathers of Greek football, 27 and Hill, The Fix, 15.

9. See European Commission, Match-fixing in sport.

10. See Mason, Sports product, 402.

11. It is perhaps interesting to note that there is a weekly TV show in a major national network (SKAI) focusing on football match-fixing as well as other corrupt practices in Greek football.

12. See The Guardian, Greek Match-fixing Allegations, 15.

13. Mplounas, Apaksiomeno to Elliniko Podosfairo, 6.

14. Ibid.

15. Kovac, Europe's Football Battlefield, 18.

16. See Brooks et al., Fraud, corruption and sport.

17. See Engelberg et al., Sport Anti-Doping in Australia, 84 and Moston et al., Drug use in Australian sport, 64.

18. Gorse \& Chadwick, Conceptualising Corruption in Sport, 40.

19. Sarasvathy, Causation and effectuation, 245.

20. See European Journalism Centre, Media Landscape: Greece.

21. Transparency International, Staying on Side.

22. See Segal, Academe in sports integrity.

23. See note 19 above.

24. Super League Greece, Annual Report, 54.

25. See also Haberfeld \& Sheehan, Match-fixing in international sports.

26. Abbott \& Sheehan, INTERPOL in tackling match-fixing, 282.

27. Ibid.

28. Jones, Compliance as prevention, 199.

29. UEFA, Financial fair play.

30. See Dimitropoulos, The accounting legislation of Greek football.

31. UEFA, Sports Betting Fraud Detection.

32. See Proto Thema, Fixed matches revealed, 2.

33. UEFA, Disciplinary updates.

34. See note 5 above.

35. Eleftherotypia, More accused of match-fixing, 12.

36. See Skokas, Illegal bookmaker, 13.

37. Triandafyllou, Football clubs' income, 23.

38. Kathimerini, Fixed matches, 48

39. Kathimerini, Income distribution, 48.

40. See note 28 above.

41. To Vima, Tackling taxation corruption, 8.

42. Eleftherotypia, Vasileio paranomias, 33.

43. See Maennig, Economics of sport corruption.

44. See Gardiner and Naidoo, Front foot against corruption and Ibid.

45. Dabilis, Greek football turns ugly, 49.

46. Efimerida Kyverniseos, Law 2725/1999/A-121, 10.

47. See note 29 above.

48. Ibid.

49. See note 26 above.

50. See Nassif, Corruption in sport.

51. Dimitropoulos, Financial performance of Greek football.

52. See note 33 above. 
53. Papachristou, Shipping tycoon makes political foray and Kathimerini, Volos Mayor Beos to face trial, 34.

54. See Manoli \& Antonopoulos, The only game in town?

55. Eleftherotypia, Greek «monopoly», 39.

56. Szymanski \& Kesenne, Competitive Balance in Team Sports.

57. Schmidt \& Berri, Competitive Balance and Attendance.

58. Direction Business Reports, Football clubs' revenue 2013/14.

59. See Buzzacchi et al., Equality of outcome.

60. See note 51 above.

61. One of the top and most popular Greek clubs, AEK, was a casualty of this situation declaring bankruptcy and seeking relegation to third division in 2013.

62. Siemos, Football's contribution to Greek economy.

63. FIFPro, FIFPRO warns players.

64. As well as Cyprus and Turkey.

65. Slater, Life in Europe's leagues and Hill, Jumping into fixing, 218.

66. See Antonopoulos \& Hall, Death of Legitimate Merchant.

67. See Kihl, Hiding behind the rules.

68. See Hall, Theorising crime and deviance.

69. See Hobbs, Lush life.

70. See note 62 above.

71. Hall, Theorising crime and deviance and Hall \& Antonopoulos, Reluctant 


\section{References}

Abbott, J., \& Sheehan, D. (2013). The INTERPOL approach to tackling match-fixing in football. In

M. Haberfeld \& D. Sheehan (Eds.), Match-fixing in international sports (pp. 263-288)

London: Springer.

Afxanonde k plithinonde oi katigoroumenoi gia ta stimena. (2013, May 19). Eleftherotypia, p. 12.

Antonakas, N. P., Konstantopoulos, N., \& Seimenis, I. (2014). Human Resource Management's Role in the Public Sector and the Level of Corruption: The Case of Greek Tax Administration Procedia. Social and Behavioral Sciences, 148, 455-462.

Antonopoulos, G.A., \& Hall, S. (2014). The Death of the Legitimate Merchant?. In P. C. van Duyne, J. Harvey, G. A. Antonopoulos, A. Maljevic, A. Markovska, \& J. von Lampe, (Eds.), Corruption, Greed and Crime Money (pp. 313-336). Nijmegen: WLP.

Brooks, G., Aleem, A., \& Button, M. (2013). Fraud, corruption and sport. Basingstoke: Palgrave Macmillan.

Buzzacchi, L., Szymanski, S., \& Valletti, T. (2004). Equality of Opportunity and Equality of Outcome. Journal of Industry, Competition and Trade, 3(3), 167-186.

Dabilis, A. (2011, November 21). Greek Football Turns Ugly. Southeast European Times, p. 49.

de Quettevillem, H. (2003, February 2). 'Godfathers' of Greek football face crackdown. The Telegraph, p. 27.

Dimitropoulos, P. (2006). The accounting and tax legislation of the Greek Football clubs. Choregia, 2(1), 55-64. 
Dimitropoulos, P. (2010). The Financial Performance of the Greek Football. Choregia, 6(1), 5-28.

Direction Business Reports. (2015). Football Clubs' revenue 2013/14. Athens: Direction Business Network

Efimerida Kyverniseos. (1999). Law 2725/1999/A-121 Amateur-Professional Sports. FEK A' 121/17.6.1999, p. 10 .

Engelberg, T., Moston, S., \& Skinner, J. (2011). Public Perception of Sport Anti-Doping Policy in Australia. Drugs: Education, Prevention \& Policy, 19(1): 84-87.

European Commission. (2012). Match-Fixing in Sport: A Mapping of Criminal Law Provisions in EU-27. Brussels: European Commission.

European Journalism Centre (2010) ‘Media Landscape: Greece', European Journalism Centre.

Available online at: http://www.ejc.net/media_landscape/article/greece/. Accessed on July 14, 2016

FIFPro. (2013). FIFPRO warns players of clubs' non-payment. FIFPro. Retreived from http://www.fifpro.org/en/news/fifpro-warns-players-of-clubs-nonpayment

Gardiner, S.. \& Naidoo, U. (2007). On the front foot against corruption. Sport Law Journal, 15, 1627.

Gorse, S., \& Chadwick, S. (2010). Conceptualising Corruption in Sport. European Business Review, July/August, p. 40-45.

Greek «monopoly». (2013, March 12). Eleftherotypia, p. 39. 
Haberfeld, M., \& Sheehan, D. (Eds.) (2013). Match-Fixing in International Sports. New York: Springer.

Hall, S. (2012). Theorising Crime and Deviance. London: Sage.

Hall, S., \& Antonopoulos, G.A. (2016). Troika, Austerity and the Reluctant Resort to Criminality in Greece. In D. Whyte, \& J. Wiegratz, (Eds.) Neoliberalism and the Moral Economy of Fraud. London: Routledge.

Hill, D. (2010). The Fix: Soccer and Organised Crime. London: McClelland \& Stewart.

Hill, D. (2015). Jumping into Fixing. Trends in Organised Crime, 18(3), 212-228.

Hobbs, D. (2013). Lush Life. Oxford: OUP.

Homewood, B. (2015, June 30). Olympiakos Champions League spot safe for now. Reuters.

Retrieved from http://uk.reuters.com/article/2015/06/30/uk-soccer-uefa-greece$\underline{\text { idUKKCNOPA21120150630 }}$

Jennings, A. (2016). The Dirty Game: Uncovering the Scandal of FIFA. London: Century.

Jones, K.L. (2013). Compliance mechanism as a tool of prevention. In M. Haberfeld \& D. Sheehan (Eds.), Match-fixing in international sports (pp. 199-228). London: Springer.

Kapranos, D. (2002, April 7). O ‘Theios’, o ‘Kokkaliaris’ kai o 'Periergos'. Kathimerini, p. 34.

Kihl, L. (2007). Moral codes, moral tensions and hiding behind the rules: A snapshot of athletic administrators' practical morality. Sport Management Review, 10(3), 279-305.

Kovac, A. (2014, September 26). Europe's Football Battlefield. International Policy Digest, p. 18.

Krataei xronia afti i...mpoxa. (2011, March 13). Eleftherotypia, p. 46. 
Lambropoulou, E. (2012). Myths and Realities About Corruption in Public Administration and its Discourse in Greece. Amsterdam Law Forum, 4 (3), 77-96.

Livanios, S. (2014, September 17). Vasileio paranomias. Eleftherotypia, p. 33.

Maennig, W. (2002). On the economics of doping and corruption in international sports. Journal of Sports Economics, 3(1), 61-89.

Maennig, W. (2005). Corruption in International Sports and Sport Management. European Sport Management Quarterly, 5(2), 187-225.

Manoli, A.E. \& Antonopoulos, G. (2015). 'The only game in town?': football match-fixing in Greece. Trends in Organised Crime, 18(3), 196-211.

Mason, D.S. (1999). What is the sports product and who buys it?. European Journal of Marketing, $33(3 / 4), 402-418$.

Moston, S., Skinner, J., \& Engelberg, T. (2012). Perceived incidence of drug use in Australian sport. Sport in Society, 15(1), 64-77.

Mplounas, T. (2014, November 11). Apaksiomeno to Elliniko Podosfairo. Kathimerini, p. 6-7.

Nassif, N. (2014). Corruption in Sport. Middle East Law and Governance, 6(2), 123-140.

Papachristou, H. (2014). Shipping tycoon makes rare political foray in Greek port town. Reuters. Retrieved from

Pos dianemondai i eisprakseis kai pou kataligoun ta esoda. (2012, January 29). Kathimerini, p. 48. Rumsby. B. (2015, July 15). Match-fixing case in Greece just adds to sense of Greek chaos. The Telegraph, p. 17. 
Sarasvathy, S. D. (2001). Causation and effectuation: Toward a theoretical shift from economic inevitability to entrepreneurial contingency. Academy of management Review, 26(2), 243-263.

Schmidt, M., \& Berri, D. (2001). Competitive Balance and Attendance. Journal of Sports Economics, 2(1), 145-167.

Segal, L. (2013). The role of the academe in sports integrity: the objectives and shape of a sports integrity training course. In M. Haberfeld \& D. Sheehan (Eds.), Match-fixing in international sports (pp. 303-330). London: Springer.

Siemos, V. (2014). Epaggelmatiko Podosfairo \& I Syneisfora tou stin Elliniki Economia. Presentation, Greek Super League, Athens.

Siomopoulos, D. (2013, May 10). To sxedio gia tin katapolemisi tis diafthoras se efories kai teloneia. To Vima, p. 8-9.

Sixteen Reportedly Charged in Greek Match-fixing Allegations. (2014, December 4). The Guardian, p. 15 .

Skokas, I. (2012, October 21). Epaggelma, Paranomos Book. To Vima, p. 13-14.

Slater, M. (2013). Goalkeeper Daniel Lloyd-Weston's tale of life in Europe's IOU leagues. BBC sport. Retrieved from http://www.bbc.co.uk/sport/0/football/23802214.

Sti fora ta ypopta pexnidia. (2010, April 26). Proto Thema, p. 2.

Super League Greece. (2013). Annual Report. Athens: Super League Greece.

Szymanski, S., \& Kesenne, S. (2004). Competitive Balance and Gate Revenue Sharing in Team Sports. Journal of Industrial Economics, 52(1), 165-177. 
Transparency International (2016) Greece. Accessed on 30 September 2016, available at:

http://www.transparency.org/country\#GRC

Transparency International. (2013). Staying on Side. Berlin: Transparency International.

Triandafyllou, A. (2012, September 9). Erevna: ta esoda ton omadon tis Superleague. Goal, p. 23.

UEFA. (2014). Sports Betting Monitoring and Fraud Detection Systems. The Hague: UEFA.

UEFA. (2015a, June 30). Financial fair play. UEFA. Retrieved from

http://www.uefa.com/community/news/newsid=2064391.html

UEFA. (2015b, October 5). Disciplinary updates. UEFA. Retrieved from

http://www.uefa.org/disciplinary/index.html

Volos Mayor Beos among 85 to face trial over match-fixing. (2015, July 30). Kathimerini, p. 34. 